Ockham on Judgment, Concepts, and the Problem of Intentionality

Author(s): Susan Brower-Toland

Source: Canadian Journal of Philosophy, Vol. 37, No. 1 (Mar., 2007), pp. 67-109

Published by: Canadian Journal of Philosophy

Stable URL: http://www.jstor.org/stable/40232310

Accessed: 07-10-2015 20:12 UTC

Your use of the JSTOR archive indicates your acceptance of the Terms \& Conditions of Use, available at http://www.jstor.org/page/ info/about/policies/terms.jsp

JSTOR is a not-for-profit service that helps scholars, researchers, and students discover, use, and build upon a wide range of content in a trusted digital archive. We use information technology and tools to increase productivity and facilitate new forms of scholarship. For more information about JSTOR, please contact support@jstor.org. 


\title{
Ockham on Judgment, Concepts, and The Problem of Intentionality
}

\author{
SUSAN BROWER-TOLAND \\ Saint Louis University \\ St. Louis, MO 63108 \\ USA
}

\section{Introduction}

In this paper I examine William Ockham's theory of judgment - in particular, his account of the nature and ontological status of its objects. ${ }^{1}$ 'Judgment' (Latin iudicio) is the expression Ockham and other medieval thinkers use to refer to a certain subset of what philosophers nowadays call 'propositional attitudes.' Judgments include all and only those mental states in which a subject not only entertains a given propositional content, but also takes some positive stance with respect to its truth. For Ockham, therefore, as for other medievals, a judgment is a type of mental state that includes attitudes such as belief, knowledge, opinion, doubt, faith, and so on. ${ }^{2}$

1 Citations of Ockham's Latin texts are to Ockham (1967-88). I rely on works from both the Opera Philosophica $(=O P h)$ and the Opera Theologica $(=O T h)$. I use the following abbreviations in referring to particular volumes:

Expos.Perih. $=$ Expositio in Librum Perihermenias Aristotelis

Expos.Phys. $=$ Expositio in Libros Physicorum Aristotelis

Ord. $=$ Ordinatio. Scriptum in Librum Primum Sententiarum

Quodl. $=$ Quodlibeta Septem

Qq.Phys. = Quaestiones in Libros Physicorum Aristotelis

Rep. $=$ Reportatio. Scriptum in Librum Primum Sententiarum

$S L=$ Summa Logicae

Unless otherwise noted, translations are mine.

2 Like other medieval thinkers, Ockham distinguishes between two types of propositional attitude: judicative (which belong to intellect) and appetitive (which belong 
There is a longstanding interpretation according to which Ockham holds, throughout his career, the view that certain mind-dependent entities - what he calls 'mental propositions' (propositiones in mente) or 'complex concepts' (complexi) - serve as objects for belief, knowledge, and other propositional (or better, judicative) attitudes. On the surface, there is much to recommend this interpretation. In a number of texts, spanning the whole of his career, Ockham explicitly states that objects of judgment are mental entities. For example, he tells us in his commentary on Aristotle's Physics (a work that dates among his latest writings) that since 'all knowledge (scientia) is in relation to a [mental] proposition or propositions,' the objects known to us 'by natural science are composed not of sensible things or substances, but of mental contents (intentiones) or concepts. ${ }^{3}$ Indeed, because of remarks such as these, Ockham became notorious in his own day for defending a kind of anti-realist view about objects of judgment. What is more, because this position was regarded by his contemporaries and successors as highly implausible, it had the effect of generating widespread debate about the matter. ${ }^{4}$

My purpose in this paper is two-fold. First, I want to show that the standard interpretation of Ockham's account of objects of judgment represents a misunderstanding: Ockham's commentators - both medieval and recent - have failed to appreciate the precise way in which his views about judgment evolve over the course of his career. In order to redress this failure, I undertake a systematic examination of Ockham's theory of judgment, identifying the various phases of its development and demonstrating that Ockham ultimately abandons the very view he became so notorious for defending. Second, I want to show that careful attention to the various stages in Ockham's thinking about judgment sheds new light on broader, and hitherto unnoticed, developments in his philosophy of mind.

to will). Attitudes falling under the category of judgment all involve an attitude about the truth of a propositional content, and so comprise only a subset of possible propositional attitudes. Attitudes about the desirability of a given propositional content - attitudes such as desiring, wishing, and hoping are acts associated with the connative or desiderative power - that is, with the will.

3 Expos.Phys. Prol., sec. 4 (OPh IV, 11). Cf. SL III-2, qq. 1-12 (OPh I, 505-526).

4 For example, at University of Oxford, Walter Chatton, William Crathorn, Robert Holcot, and Adam Wodeham (all of whom are near contemporaries of Ockham) take up the question about objects of judgment, and do so explicitly in reaction to Ockham. At Paris, Walter Burleigh, John Buridan, among others, discuss Ockham's views. See Brower-Toland 2002, Grassi 1990, and Nuchelmans 1973, chs. 12-14. 
In some ways, the claim that Ockham's views about judgment and its objects evolve over time will not be news to those familiar with his philosophy. Commentators who have explicitly treated Ockham's account of judgment have recognized that his account undergoes some development - specifically, a development occasioned by the wellknown shift in his views about the nature of concepts. ${ }^{5}$ Thus, whereas in his early writings Ockham endorses a view according to which concepts are mind-dependent thought-objects called 'ficta,' in his most mature writings, he rejects this view in favor of a 'mental-act theory,' according to which concepts are not items distinct from and dependent on mental acts, but are rather identified with mental acts themselves. ${ }^{6}$ It is clear that this well-known shift in Ockham's account of concepts requires some sort of change in his account of the objects of judgment, since he takes the mental propositions that serve as such objects to be complex concepts. Thus, to the extent that commentators have addressed the issue explicitly, they have typically inferred that Ockham develops two accounts of judgment - one corresponding to each of his two accounts of concepts.

In what follows, I argue that, as tempting as it is, this picture is inaccurate on several counts. In the first place, Ockham develops not two but three theories of judgment. What is more, the developments in his theory of judgment, while importantly connected to changes in his account of concepts, must be understood in terms of a broader and more fundamental shift in his views about the nature of intentionality itself.

5 'Concept' translates the Latin expression conceptus (literally, what is thought or conceived). The medieval notion of a concept corresponds roughly to the early modern notion of an idea - which isn't to say that there is any more agreement among medieval authors than among early modern about the precise nature of such entities. In fact, there are interesting parallels (and perhaps historical connections) between medieval disputes about the nature of concepts and early modern disputes about the nature of ideas.

6 Ockham's writings on concepts have been divided into three main periods: An early period during which he advanced the fictum theory, a middle period during which Ockham defends both the fictum and the mental act theory as equally plausible views, and a later period during which Ockham wholly endorses the mental-act theory. The earliest drafts of his Sentences commentary - that is, his Reportatio commentary and the early draft of his Ordinatio - belong to the early period. To the middle period belong his later additions to the Ordinatio commentary and his commentary on the Perihermenias. The Quodlibetal Questions, the Questions on the Physics, and the Summa Logicae all belong to the last period. For relative dating of these texts, see Boehner 1946 and 1951 and Leff 1975, ch. 2.

7 For two recent examples of this sort of interpretation, see Karger 1995, 171-96 and Pasnau 1997, 285-9. Karger and Pasnau diverge, however, in their characterization what these two theories are. See Section II below 
Indeed, it is this very shift in Ockham's account of intentionality that, I shall argue, ultimately underlies his move from the fictum to the mentalact account of concepts. Thus, in addition to correcting a longstanding misinterpretation of Ockham's theory of judgment, I also take myself to be filling an important lacuna in the contemporary literature surrounding Ockham's account of concepts. ${ }^{8}$ For, while scholars are well aware that Ockham's views about concepts figure prominently in his thinking about a wide range of philosophical issues, little attention has been given to the precise way in which his views about concepts are connected to his views about judgment and about intentionality. As will emerge, however, a complete account of the developments in Ockham's views about concepts requires us to view them from the vantage point of his thinking about judgment and about intentionality generally.

The paper is divided into four sections. In Section I, I examine Ockham's earliest treatment of judgment in his Ordinatio commentary focusing in particular on the relation between it and his early, fictum-theory of concepts. Here I argue that Ockham's early views about both concepts and judgment are motivated by what I call a 'relational analysis' of intentionality. Having established the relationship between Ockham's early theory of judgment and his views about both concepts and intentionality, I go on, in the remainder of the paper, to examine how these connections bear on subsequent developments in his thinking about judgment. In Section II, I focus on Ockham's commentary on De Interpretatione where he develops his second or 'intermediate' theory of judgment; and in Section III, I examine Ockham's third and most mature discussion of judgment in his Quodlibetal Questions. ${ }^{9}$ As will become clear

8 The literature on Ockham's account of concepts is vast - and for good reason. Not only is the relative dating of many works in Ockham's philosophical and theological corpus established by reference to developments in his account of concepts, but also Ockham's account of concepts is central to his defense of a number of his most characteristic doctrines including his nominalism in metaphysics and his direct realism in epistemology. As a result, Ockham's rejection of ficta and subsequent move to the mental-act has been discussed extensively in contemporary Ockham scholarship. Typically, the shift is explained as motivated by his coming to be convinced, largely under pressure from his fellow Franciscan, Walter Chatton, that such entities are both metaphysically suspect and a threat to a direct realist account of perception. For a representative account of this see Adams 1977. I return to this issue in Section IV.

9 Thus the texts on which I rely for the three-fold development in Ockham's account of judgment are the same as those through which scholars have traced the threestage development in his account of concepts. See note 4 above for the relative dating of these texts. 
from my discussion in these two sections, if we want to understand Ockham's views about judgment, we cannot, as his commentators have often supposed, merely look to changes in his account of concepts. On the contrary, we must look to the development in his attitude toward the relational analysis of intentionality. For, in the end, it is Ockham's views about the nature of intentionality that shape his account of both concepts and judgment.

In the fourth and final section of the paper, I call attention to a final, systematic virtue of my interpretation. In particular, I argue that, in addition to making the best sense of the texts, my interpretation has the added benefit of resolving some outstanding difficulties for the received account of Ockham's transition from the fictum to the mental-act theory of concepts.

\section{Ockham's early theory of judgment}

Ockham's account of judgment forms one part of a much broader theory about the nature and types of human cognition. In order to understand his early account of judgment, therefore, it will be useful to begin by situating it within this broader framework.

\section{Intentional Acts: Judgment, Apprehension, and Other Mental States}

Like many later medieval philosophers, Ockham conceives of mental states as concrete mental particulars, claiming that they are a type of Aristotelian accident that inheres in the mind or soul as their subject. As he explains, 'an act of intellection' - that is, an act of intellectual cognition - 'and, in general, every accident that informs the soul is a true quality in just the way that heat or whiteness is. ${ }^{10}$ Mental acts or states are, thus accidents that fall in the Aristotelian category of Quality.

It should be noted at this point that although it is standard for medieval philosophers to speak of belief, knowledge, and other cognitive states as mental acts, in so speaking they don't mean by 'act' activity or action but something more like actualization. ${ }^{11}$ Medieval authors refer to belief

10 Ord. d.2, q.8 (OTh II, 273). Ockham's Ordinatio d.2, qq. 4-8 can be found in English translation in Ockham 1994, 114-231. I adopt, with some modification, Spade's translations of the relevant passages from Ord. d.2, q.8.

11 Philosophers have sometimes worried that speaking of mental 'acts' is problematic 
and knowledge as mental 'acts' because, on their view, to believe or to know something is to actualize certain cognitive or rational capacities. An act of belief (or of cognition generally), therefore, is not to be understood as a mental activity per se, but rather as something more like an occurent mental state. ${ }^{12}$

Ockham distinguishes among several different types of mental act, including intellective, volitional, and sensory. For our purposes, in what follows, we will be concerned only with his account of intellective states (intellectiones), which can be thought of roughly as states of thinking or conceiving. In the prologue of his Ordinatio, Ockham claims that all intellective acts or states fall into one of two categories: apprehension or judgment. As he explains:

(A) There are two kinds of act [to be distinguished] among the intellect's acts. The first is an act of apprehension and it relates to everything that terminates an act of the intellective power, whether this be something complex or something non-complex. For we apprehend not only things which are non-complex, but also propositions (propositiones), demonstrations, impossibilities, necessities, and, in general, anything that is regarded by the intellective power. The second type of act may be called an act of judgment. It is that act by which the intellect not only apprehends its object, but also gives its assent or dissent to it. This act is only in relation to a proposition (complexi). For our intellect does not assent to anything unless we consider it to be true and it does not dissent from anything unless we judge it to be false. And so it is clear that, with respect to a proposition (complexi), there can be two acts, namely an act of apprehension and an act of judgment. ${ }^{13}$

inasmuch as it suggests that belief, knowledge, and other such attitudes are a type of activity or action. Thus, for example, John Searle has objected to the notion of mental acts on the grounds that this conception is 'at best false, and at worst hopelessly confused.' As Searle explains, 'acts are things one does, but there is no answer to the question "What are you now doing?" which goes, "I am now believing it will rain" or "hoping taxes will be lowered" or "fearing a fall in the interest rate"' (Searle, 1983, 3). By clarifying medieval terminology I mean to fend off worries of this sort.

12 So understood, these mental qualities or acts are entities of discrete and relatively short duration since, in general, occurent conscious states (such as cognizing, willing, judging and the like) are of discrete and relatively short duration. Although medieval thinkers typically speak of cognizing, believing, and other psychological states or attitudes as 'acts' and, hence, as occurent states, they also recognize another type of mental state or quality - what they call a 'habit.' These qualities are of much longer duration and, unlike mental acts, which are conscious mental states, they are unconscious, dispositional mental states. Habits are, on Ockham's view, produced by acts and remain in the mind long after them as dispositions for similar conscious acts. Since such habits are, on Ockham's view, not mere potentialities, but rather first actualities, there is a sense in which they too can be called 'acts.' 
As this passage makes clear, Ockham's distinction between apprehension and judgment is drawn in part by the type of object to which such acts relate. Acts of apprehension, he tells us, may be directed at either 'complex' or 'non-complex' objects - which, I take it, is just his way of saying that they can be either propositional or non-propositional in content. Judicative attitudes are, by contrast, always propositional in content - hence, Ockham's claim that such states occur 'only in relation to a proposition. ${ }^{14}$

Apprehension and judgment differ not only with respect to their objects, however, but also with respect to the specific mode of awareness or psychological attitude they involve. Ockham takes apprehension to be a mental state in which the intellect neutrally considers some object without taking any definite attitude toward it, whereas judgment is a state in which 'the intellect not only apprehends its object, but also gives its assent or dissent to it.' Indeed, as Ockham goes on to point out, the further attitude involved in judgment always concerns the truth or falsity of what is judged. This explains why apprehension and judgment are individuated, at least in part, by their objects. One can neutrally consider something that is either propositional or non-propositional in content, but insofar as acts of judgment involve an attitude toward the truth or falsity of what is judged, they are distinctively propositional acts or attitudes. ${ }^{15}$

Throughout his career, Ockham characterizes intellective acts or states in terms of their essential aboutness - that is to say, in terms of their

13 Ord. Prol., q. 1 (OTh I, 16). Selections from q. 1 of the Ordinatio prologue can be found in English translation in Ockham 1990, 18-25.

14 As it turns out, apprehension and judgment are each a type of mental state admitting of further subdivision. As Ockham indicates in passage (A), for example, judgment may be divided into assent and dissent - where assent is an attitude of affirming the truth of the apprehended object and dissent is an attitude that denies the truth of the object. Acts of assent and dissent can, moreover, be further divided into more specific propositional attitudes such as knowing, believing, opining, doubting and so on. Apprehension can, likewise, be further subdivided. As passage (A) makes clear, some apprehensions are propositional apprehensions (namely, acts of entertaining propositional contents), but other apprehensions are non-propositional. In fact, Ockham goes on later in his discussion in the Ordinatio prologue, to distinguish between two types of non-propositional (intellective) apprehension: 'intuitive' and 'abstractive' cognition.

15 It may be that there is distinction to be drawn between acts and attitudes according to which acts are occurent mental events of discrete duration, whereas attitudes are longstanding states or dispositions. Nevertheless, since nothing I say turns on such a distinction I use the terms interchangeably. 
intentionality. Indeed, as he puts it at one point: 'it is a contradiction to suppose that there is an act of thinking (intellectio) in the intellect without there being something that is thought (intelligatur). ${ }^{16}$ Yet while Ockham always insists that intellective acts are essentially intentional, we shall see that his analysis of what their intentionality consists in changes over time. Early on, Ockham takes for granted that the intentionality of mental states is to be analyzed straightforwardly as a relation, namely, a relation between a mental act on the one hand, and some object on the other. This view is perhaps nowhere more evident than in passage (A) above where Ockham characterizes apprehension and judgment as acts that 'relate to' or 'terminate at' certain types of object; indeed, as we've just seen, he thinks such acts are individuated in part by the kind of object to which they relate. Thus, his early account of the intentionality of mental acts constitutes what, for convenience sake, we might call a 'relational analysis' of intentionality since it analyzes intentionality as a relation between intentional acts, on the one hand, and certain objects, on the other.

This sort of analysis of intentionality is familiar in the history of philosophy. ${ }^{17}$ And there is no difficulty seeing what would have attracted Ockham to it. Such an analysis provides both a natural characterization of the aboutness of thought and a straightforward means for individuating mental states. Indeed, if we reflect on the nature of intentional states it seems perfectly natural to render them in terms of the two elements to which Ockham's early analysis appeals: their content (i.e., this act is a thought of a square, that act is a thought of a circle), and the particular psychological attitude they involve (this act is an act of merely entertaining the thought that a square is not a rectangle, that act is the act of believing that a square is not a rectangle). It is not surprising, therefore, that in the discussion following that quoted in passage (A), Ockham goes on to defend his analysis of intentional states along just these lines:

16 Quodl. IV, q.35 (OTh IX, 473).

17 The literature treating of this sort of view both historically, and non-historically is vast. Perhaps one of the best discussions is to be found in David Woodruff-Smith and Ronald McIntire 1982, ch. 2. Using different terminology (their preferred label is 'object-theory of intentionality,' but the view itself is the same; see p. 42) they trace this view in the early Brentano and Meinong drawing comparisons to Frege along the way. Sellars $(1963,41 \mathrm{ff}$.) traces this sort of view in early modern period and in early $20^{\text {th }}$ century period. Other useful discussions of this sort of approach to intentionality include: Addis 1989, 34-42; Aquila 1977, ch. 2; Haldane 1989, 1-32; McDowell 1998, 476 ff. 
(B) I hold that an act is distinguished by its object, since it is always the case that a specific distinction among acts follows from a distinction among objects - as when objects are apprehended by one of these acts and not by another. It does not follow from the identity of the object, however, that there is an identity of acts. For example, if $\mathrm{A}$ is an object of an act of thinking (intellectionis) and $\mathrm{B}$ is an object of an act of willing, it follows that thinking of A and willing B are distinct acts. $^{18}$

Nowadays, we customarily distinguish between different kinds or aspects of intentionality - in particular, between what we might call content intentionality (a mental state's having representational content) and referential intentionality (a mental state's being directed at or about a given object). ${ }^{19}$ As it turns out, Ockham eventually comes to mark this sort of distinction, but in his early discussions of intentional acts, he seems not to be aware of it. Indeed, the way he initially individuates intentional acts - that is, just in terms their object and psychological attitude - is evidence of this. As we've seen, Ockham holds that what distinguishes one mental act from another involving the same attitude is its content, but then he appears to simply take for granted that a mental act's having a given content consists in its being directed at or related to some object.

Before turning to Ockham's early discussion of intentional objects, I need to call attention to one final feature of his account of intentional acts - namely, his analysis of the relations that obtain among the various types of mental act. For, in the Ordinatio prologue, immediately after introducing the distinction between apprehension and judgment, Ockham proceeds to argue for a certain ordering among the intellect's various acts. He begins by arguing that acts of apprehension are logically prior to acts of judgment:

(C) An act of judgment relating to some proposition presupposes an act of apprehension relating to the same proposition.... And this act of apprehending can

18 Ord. Prol., q. 1 (OTh I, 62).

19 I am here adopting terminology used by $\operatorname{Kim}(1996,21)$, but the distinction is one common to discussions of intentionality and has been expressed in a variety of ways by a variety of philosophers. Crane (2001, 6-33) who (following Searle) labels these two elements of an intentional state its 'aspectual shape' and 'directedness' respectively. Haugland $(1990,384)$ expresses it by pointing out that 'that something's content is not the same as what it is about or represents.' More historically (e.g. especially among members of the Brentano school), the distinction has been drawn simply as a distinction between the content and the object of intentional states. See, for example, Findlay 1963, ch. 1; Jan Woleńki 1998/99, 15-35; Woodruff-Smith and McIntyre 1982, ch. 3. 
exist without an act of judgment, but not vice-versa. Therefore, apprehension is naturally prior [to judgment] - the former presupposes the latter. ${ }^{20}$

According to Ockham, every judgment presupposes a logically prior act of apprehending, since in order to form a judgment regarding some content one must first apprehend what is to be judged.

Along the same lines, Ockham claims that propositional apprehensions presuppose, in their turn, certain 'simple' acts of apprehension that is, apprehension or grasp of the non-propositional 'terms' or conceptual constituents of the proposition apprehended. Thus, on his view, the occurrence of any given act of judgment will always involve several (logically) prior acts of apprehension. As he says:

(D) Every act of judgment presupposes in the same faculty a non-propositional grasp of its terms; for it presupposes an act of apprehending [a proposition] and the act of apprehending a proposition presupposes a non-propositional grasp of the terms of that proposition. ${ }^{21}$

On Ockham's early account, therefore, judgment is a complex psychological event - one involving a network of relations among various intellective acts and objects.

\section{Intentional Objects: Concepts, Ficta, and Objects of Judgment}

Thus far, we have been focusing on Ockham's early account of intentional acts. I want to turn now to examine his account of the objects of such acts. Ockham's early account of intentional objects is driven by a problem associated with the relational analysis of intentionality. On this analysis, as we've seen, every act of thinking relates to an object. Indeed, as Ockham himself points out, for any given mental act one may ask: 'Is something understood by this cognition - or is nothing understood?' In response, he argues:

(E) It cannot be said that nothing is. For in just the way that it is impossible that there should be vision and nothing seen, or that there should be desire and nothing desired, so also it is impossible that there should be a cognition and nothing cognized by that cognition. ${ }^{22}$

20 Ord. Prol., q. 1 (OTh I, 17-8).

21 Ord. Prol., q. 1 (OTh I, 21).

22 'Non potest dici quod nihil, quia sicut impossibile est esse visionem et nihil videri, vel esse dilectionem et nihil diligi, ita impossibile est esse cognitionem et nihil cognosci illa cognitione.' Expos.Perih. Prol., sec. 6 (OPh II, 352). 
As Ockham recognizes, this analysis of thought gives rise to certain puzzles. In cases where thought is about what exists, there is perhaps little difficulty in accounting for the objects of thought. But what is to be said about those cases in which we think of what doesn't exist? To what are mental acts related in such cases?

This problem, the so-called 'problem of intentionality,' arises directly out of Ockham's commitment to the relational analysis of intentionality and is perhaps as familiar as the relational analysis itself. ${ }^{23}$ The problem is one that emerges directly from Ockham's commitment to three intuitive theses about thought (the first of which is just a statement of the relational analysis itself):

(i) Thinking consists in a relation between an act of thinking and what is thought of.

(ii) Relations entail the existence of their relata.

(iii) We can (and sometimes do) think of what does not exist.

The difficulty, of course, is that the conjunction of the first and the third claims entails that thought can be related to non-existent things, whereas the second denies this.

Now, in order to see how Ockham resolves the problem of intentionality, we need to turn to his early discussion of universals at Question 2, article 8 of the Ordinatio (hereafter, 'Q.2.8'). It should not be surprising that Ockham addresses the problem of intentionality in the context of his treatment of universals, since while Ockham would certainly not deny that we have thoughts that are universal in content, he does deny that universals exist. ${ }^{24}$ Thus at the outset of the question, Ockham observes that 'in every act of thinking there is something that is thought,' adding a bit later that 'that which terminates an act of thinking is what everyone calls the mind's 'concept' (conceptus). ${ }^{, 25}$ But if there are no

23 For a discussion of the problem of intentionality see, for example, Crane 2001,336-49 and Harney 1984, ch. 1. A discussion of the issue among ancient thinkers can be found in Caston 1993 and 1998, 249-98.

24 Not only does he deny that there are universals, but thinks that 'to suppose that there is something in extramental reality besides singulars is ... altogether absurd and destructive of the whole of Aristotelian philosophy and of all knowledge, all truth, and all reason. I believe it to be the worst error in philosophy.' Expos.Perih. Prol., sec. 8 (OPh II, 363). 
universals, what is the nature of that which is conceived (conceptus) by acts that are universal in content? It is this question that Ockham sets out to answer in Q.2.8.

Although in this context Ockham raises the problem of intentionality specifically for universals, he is well aware that the problem arises for thought about non-existents generally - and, given his penchant for ontological parsimony, there are, for him, many such cases. ${ }^{26}$ Even so, his favorite examples to illustrate the problem involve purportedly abstract entities. Thus in Q.2.8, in addition to citing universals, he also mentions 'propositions, syllogisms, and other items with which logic deals' - all of which, according to Ockham, do not exist. ${ }^{27}$ As he explains: 'propositions, syllogisms and the like, [namely, those items] with which logic deals, do not have subjective [that is, true or genuine] reality. ${ }^{28}$ Given Ockham's claim (in passage (A) and elsewhere) that acts of judgment relate to or terminate at propositions, his denial of the existence of propositions (and the like) renders the problem of intentionality particularly acute in the case of judgment.

Ockham's solution to the problem of intentionality is one that involves the introduction of a class of unreal, or intentionally existing, thoughtobjects - entities that he refers to alternatively as 'ficta,' 'objectively existing beings' (entia habentia tantum esse objectivum) or 'concepts of the

26 Ockham is, of course, well known for his nominalism. In general, he appears willing to allow only concrete, particular things (res) falling in the category of substance and quality. Thus, he seems to deny the reality not only of universals, but also of abstracta including propositions (as they are nowadays conceived), and facts or states of affairs. There is, however, a good deal of debate in the scholarship about just what Ockham does and does not admit in his ontology. Thus, while some scholars, such as Normore (1999) argue that, in addition to certain qualities and theological relations, Ockham is committed only to presently existing individuals, others hold that his commitment extends beyond this. Panaccio (1999), for example, argues that Ockham is also committed to past, future, and merely possible individuals. Spade (1999) goes so far as to claim that Ockham is even committed to certain properties or non-objectual entities.

27 In addition to these sorts of examples, Ockham also cites cases such as thoughts about possible (but non-existing) objects - for example, the things that God thinks of before he creates - and thoughts about fictive objects such as chimeras and goat-stags.

28 Ord. d.2, q.8 (OTh II, 273); Cf. Ockham 1994, 219. Of course, Ockham admits that there are (what he refers to as) 'spoken and written propositions.' Thus in claiming that there are no propositions, he's denying that there is anything in the external world beyond substances and certain qualities that might serve as the correlate or ontological ground for judgment or propositional thought in general. 
mind' (concepta mentis). ${ }^{29}$ A fictum, he tells us, 'has the aspect of an object and is what immediately terminates an act of intellective cognition (intelligendi) when no singular thing is cognized. ${ }^{30}$ Although such thought-objects, according to Ockham, do not have real (or what he calls 'subjective') existence, they do, nevertheless, possess a mode of existence that he variously refers to as 'objective,' 'intentional,' 'cognized,' or 'fictive. ${ }^{\prime 31}$ (Note that the medieval usage of the terms 'subjective' and 'objective' existence runs counter to our current usage of these expressions. Thus, for Ockham and other medieval thinkers, an objectively existing being is an intentional or mind dependent being, where a subjectively existing being is one that exists independently of (human) minds.) As Ockham explains, 'they [i.e. ficta] have only objective being so that their being is their being cognized. ${ }^{, 32}$ They are items that 'can be fashioned by the mind' as a kind of 'likeness, or image, or picture ... [or] 'word' of a thing. ${ }^{33}$ Ficta are, therefore, mental or mind-dependent, entities created by and immanently present to the mental states directed at them. ${ }^{34}$

29 Some scholars have argued (see Adams 1977, 151 n.24 and Kelly 1978, 260-282) that the expression 'ficta' is not interchangeable with the expressions 'concept' and 'objectively existing being.' According to these scholars, only a subset of concepts or objectively existing beings are ficta. While there are passages that suggest this reading, there are also passages in which he uses ' $f i c t a$ ' to refer to all intentional entities (cf. Quodl IV, q. 35). In addition, there is the fact that Ockham is quite explicit that the constituents of mental propositions are ficta, but there appears to be no restriction on what concepts can be combined by the intellect to form propositions. Although I shall continue to use these terms interchangeably, nothing in my argument turns on this usage.

30 Ord. d.2, q.8 (OTh II, 268); Cf. Ockham 1994, 220.

31 Ord. d.2, q.8 (OTh II, 271-274). Cf. Expos.Perih. Prol., sec. 7 (OPh II, 360); Quodl. IV, q. 35 (OPh IX, $469 \mathrm{ff}$ ).

32 Ord. d.2, q.8 (OTh II, 273). Cf. Expos.Perih. Prol., sec. 7 where Ockham argues that a fictum 'doesn't have being except by the operation of the mind.' As he explains, ' $[a$ fictum] can be called an intention of the mind in virtue of the fact that it isn't something real in the mind (in the way that, say, a habit is something real in the mind) but has only intentional being, that is, cognized being. And for the same reason it can be called a concept of the mind.' For a discussion of the relation between Ockham and Descartes' notion of objective being, see Normore 1987.

33 Ord. d.2, q.8 (OTh II, 270); Cf. Ockham 1994, 222.

34 In this respect, these entities are more akin to Berkelian ideas (although Ockham would not countenance Berkley's idealism) or to Brentano's 'intentionally inexistent objects' than to, say, Meinongian non-existent objects or contemporary notions of non-mental concepts. While there are some scholars (e.g., Adams (1987, chs. 11, 26) 
In light of all this, we can see that Ockham's strategy for resolving the problem of intentionality, at least in his early writings, is to adopt a theory of concepts that allows him to preserve the relational analysis that is, to preserve the first of the three theses listed at (i) - (iii) above. Doing so, however, also requires him to modify the second and third of these three theses. Thus, his version of (ii) amounts to something like:

(ii*) relations entail either the subjective or the objective existence of their relata.

And his version of (iii) is just:

(iii*) We can (and sometimes do) think of what does not subjectively exist.

Understood in this way, (i) - (iii) no longer raise any threat of inconsistency.

While Ockham introduces ficta to serve as objects for all cases of thought of non-existents, he almost always focuses on them for cases of universal cognition and propositional attitudes. ${ }^{35}$ Indeed, in his later writings, Ockham admits that the initial motivation for positing ficta was chiefly to account for thought about universals and propositions: '[a fictum] was postulated for no other reason than to stand for a thing in such a way that both a proposition might be composed out of it and it might be common to things. ${ }^{36}$ Thus, for him, the propositional objects that serve as relata of judgments (such as knowledge and belief) are just complex concepts - ficta brought together by the intellect to form a complex thought-object (complexum) or what Ockham frequently refers to as a 'mental proposition' (propositione in mente).

and Read (1977)) who resist the idea that Ockham's ficta are mental or mind dependent entities I find little textual evidence to support such readings and much to argue against it.

35 For example, at one point Ockham points out that it is clear that such a fictum is truly the object cognized by the intellect. Because of this it can be a term of a proposition and it can supposit for all things it is an image or likeness of. This is what it is to be universal and common to them' Ord. d.2 q.8 (OTh II, 279). Similarly, when Ockham discusses ficta in his commentary on De Interpretatione, he claims that: ' $[\mathrm{a}$ fictum] terminates an act of understanding when some singular outside the mind is not understood and, nevertheless, something common is understood in external things.... Moreover, from these [ficta] propositions are formed-propositions that are known and understood.' Expos.Perih. Prol., sec. 7 (OPh II, 360).

36 Expos.Perih. Prol., sec. 7 (OPh II, 360). Cf. Qq.Phys. q.1 (OPh VI, 398). 
The fact that Ockham thinks of the objects of judgment as complex concepts explains something we saw earlier - namely, his analysis of the logical relations that obtain among various mental acts. On his early account, mental propositions are the product of a certain mental operations that he refers to as 'composition.' According to Ockham: 'whatever the intellect can apprehend in a simple act of thinking, it can combine (componere) with another thing by saying 'this is that. ${ }^{, 37}$ What Ockham calls 'composition,' therefore, is just the mental state in which one forms or apprehends a mental proposition. Thus, the propositions that serve as objects of judgment are produced by and dependent on acts of apprehension - that is, on the acts by which one first forms or grasps, or 'composes' the proposition in question. In light of this, it is clear why Ockham supposes acts of judgment are (logically) posterior to various acts of apprehension. Without a (logically) prior apprehensive act of composition there is no propositional content toward which one might adopt a judicative attitude. ${ }^{38}$ Indeed, on his view, the act of assenting or dissenting depends on one's having first entertained a given propositional content. Moreover, inasmuch as forming or apprehending a proposition in turn requires an apprehension or grasp of the simple concepts that comprise it, it follows that judgments likewise presuppose the occurrence of certain non-propositional apprehensions. Thus, it is Ockham's account of the nature of concepts - his view that they are entities produced by and dependent on acts of apprehension - that motivates his views (stated in passages (C) and (D) above) about the logical ordering among acts of judging and apprehending.

\section{From Ficta to Mental Acts}

We can now see that Ockham's early theory of judgment is intimately connected to his early views about intentional acts and intentional objects in general. Indeed, it is his relational analysis of intentionality that leads him to introduce the ficta that serve as the objects for judgment in the first place. As I noted at the outset, however, Ockham comes to have second thoughts about the fictum theory of concepts. The catalyst

37 Ord. Prol., q. 1 (OTh II, 49).

38 Ockham's claims about the ordering among mental acts pertain only to the natural order. He allows that it is possible, by divine absolute power, for an act of judgment to be produced without any prior act of apprehension. See, Ord. Prol., q. 1 (OTh II, 57ff.). 
for this change of heart appears to have been Ockham's junior colleague at Oxford, a philosopher and theologian by the name of Walter Chatton, who vigorously criticized the fictum theory. ${ }^{39}$ Chatton raises a number of objections to ficta - all of which are designed to show that such entities are (a) ontologically superfluous, and (b) epistemologically problematic. In connection with the first point, Chatton argues that mental acts alone can play any role allotted to ficta: 'a [mental] act,' he says, 'is just as sufficient for representing something as a fictum is. ${ }^{\prime 40}$ In connection with the second point, he maintains that ficta are unacceptable intermediaries that get in the way of our direct cognition of extramental reality. ${ }^{41}$ Accordingly, when Chatton turns to his own account of concepts, he argues that 'there is no mediating, fictive being that immediately terminates a [mental] act ... there is only the act of thinking itself. ${ }^{, 42}$

As is well known, Ockham eventually comes to accept these criticisms of the fictum theory, and indeed to advance them (in some cases, almost word for word) as his own grounds for accepting the mental-act theory. He does not, however, arrive at the mental-act view all at once. On the contrary, for an intermediate period he regards it (along with one other alternative) as merely an equally plausible alternative to the fictum account. ${ }^{43}$ It is only in his most mature writings that Ockham finally and wholeheartedly abandons ficta.

It is clear that this development in Ockham's thinking about concepts has significant implications both for his views about judgment and its objects as well as for his account of intentionality generally. That it has implications for his account of intentionality generally will become clear

39 For a fuller discussion of Chatton's criticisms of Ockham and his role in Ockham's eventual change of mind see Gál 1967, Kelly 1981 and Tachau 1988, ch.7.

40 Chatton 2002 (Reportatio I d.3, q.2, 234).

41 Ibid., 234-5.

42 This quotation comes from the Lectura version of I d.3, q.2. See Gál 1967, 204 n. 26.

43 Thus, Ockham says of both the fictum and mental-act theories 'I think they are plausible. Nevertheless, let the studious folks (studiosi) settle which is true and which false.' Expos.Perih. Prol., sec. 10 (OPh II, 371) Actually, at this stage, Ockham is willing to grant three different possible views about the nature of concepts. Thus, in addition to the mental-act and fictum view (discussed in sections 6 and 7 of the Prologue, respectively) he expresses a willingness (in section 4) to also allow the view that a concept 'is some kind of mental quality - one that is really distinct from the act of thinking, and that terminates the act of thinking itself as its object and which, in fact, exists only when there is an act of thinking' (OPh II, 349). The only view he explicitly rules out as 'irrational' is the view that a concept is a species - a view many of his contemporaries held. 
as we go, but its implications for his account of judgment can be seen already. After all, on the fictum theory of concepts, acts of judgment take propositions as their objects, and propositions in turn are construed as complex ficta. If ficta are abandoned in favor of a mental-act theory of concepts, Ockham must revise his account to explain what, in the absence of ficta, serves as objects of judgment.

While scholars have generally recognized that Ockham is forced to modify his early theory of judgment in light of his changing theory of concepts, there is some disagreement as to what these modifications involve. Since the time of Ockham, most commentators have regarded him as holding fixed throughout his career the view that acts of judgment relate to mental entities - that is, to complex concepts, or mental propositions. Thus, the majority of commentators (including his own contemporaries and successors) would agree with the assumption made by Robert Pasnau $(1997,285-9)$ that the only modification Ockham makes to his early theory occurs in his account of the nature of mental propositions themselves - so that, whereas on the early theory, judicative attitudes relate to mental propositions understood as complex ficta, on the later theory such attitudes relate to mental propositions understood as complex mental acts. ${ }^{44}$ Other commentators, however, have thought they could detect a more radical revision in Ockham's later theory. Elizabeth Karger (1995, 171-96), for example, claims that when Ockham jettisons ficta he also abandons his early view that all acts of judgment relate to propositions. ${ }^{45}$

In light of what we've seen so far of Ockham's broader views about intentionality, Karger's account of the shift from ficta to mental acts would seem to carry with it a certain prima facie plausibility. This is because the mental-act account of concepts, at least on the face of it, appears to involve a rejection of the relational analysis of intentionality. After all, since it is Ockham's commitment to a relational analysis that leads him to introduce ficta in the first place, it is natural to suppose that

44 Other scholars who appear to take a similar line include: Adams (1987, ch. 26), Kretzmann $(1970,780-1)$, Nuchelmans $(1973,198)$, and Tachau $(1988$, chs. 5, 7 and 10). Although none of these authors explicitly treat the changes in Ockham's thinking about judgment, their discussions make clear that they assume that Ockham held - throughout his career - the view that judicative attitudes relate to mental propositions. As I indicated at the outset, Ockham's own contemporaries and successors also appear to read him as Pasnau does.

45 John Boler $(1976,88)$ also seems to gesture at this interpretation. As will become clear, Ockham - even in his most mature writings on judgment - continues to maintain that there is a sense in which some types of judicative attitude can be said to take propositions as object. I return to this complication in section III. 2 below. 
for him to reject ficta is tantamount to a rejection of the relational analysis itself - especially since he never introduces any other sort of entity to serve as the object for thoughts involving non-existent entities (and Ockham never wavers on his refusal to admit universals, propositions, etc. as mind independent entities). ${ }^{46}$ If this is right, and if the mental-act account amounts to a rejection of the relational analysis of intentionality, then we would expect Ockham also to abandon a relational analysis of judicative attitudes and so, as Karger maintains, to radically revise his early account of the objects of judgment.

Unfortunately, matters are not so simple. As we shall see, there is considerable textual evidence to suggest that, pace Karger, Ockham initially continues to maintain his early view that propositions are objects for all judicative attitudes - even in contexts in which he is expressly presupposing a mental-act theory of concepts. Such evidence certainly lends weight to the more traditional reading - that is, to the reading advanced by Pasnau and others. But if Ockham continues to hold that all judicative attitudes take mental propositions as their object, it would appear he doesn't abandon the relational analysis after all.

In the remainder of the paper, I show how these interpretive discrepancies disappear once it is recognized that Ockham develops not two but three accounts of judgment over the course of his career: one in connection with his early fictum theory of concepts and then two more in connection with the mental-act theory. As we shall see, the reason for the two-fold development in connection with the mental-act theory owes to the fact that Ockham does not immediately see how to amend his early theory of judgment to accommodate the mental-act account of concepts. Indeed, when Ockham first begins to consider and develop the mentalact theory (that is, during the intermediate period in which he is neutral between it and the fictum theory) he continues to hold a relational analysis of intentionality - at least when it comes to his analysis of judicative attitudes. In fact, what is most distinctive about what I shall call the 'intermediate theory of judgment' is that it embodies a kind of disjunctive analysis of intentionality: Ockham is willing to reject the relational analysis of intentionality for some intentional states, but then

46 Understood in this way, the difference between the fictum and the mental-act account of concepts is the difference between two views of intentionality: on the former view, Ockham analyzes intentionality relationally - a thought's having content is analyzed as a relation between the mental act itself and a certain object; on the latter view, he rejects the relational analysis and so analyzes intentionality non-relationally - or, we might say, adverbially - a thought's having content is nothing other than a mental act's being contentful in a certain way. 
retains it in his analysis of others. That Ockham should adopt this disjunctive account of intentionality is, of course, puzzling - and, eventually, I'll need to say something about why he might have come to such a view.

\section{Ockham's Intermediate theory of judgment}

Ockham's earliest attempt to modify his view of the objects of judgment in order to accommodate a mental-act account of concepts is found in the prologue of his commentary on Aristotle's De Interpretatione. In the prologue of the commentary, Ockham surveys a variety of views one might hold about the nature of concepts. While this survey is not restricted to the fictum and mental-act view, these two views receive the most attention. It is in the context of this early treatment of the mental-act account of concepts that Ockham develops what I am calling his 'intermediate' theory of judgment. $^{47}$

\section{The Context:}

\section{A Challenge for the Mental-Act Theory of Concepts}

In Section 6 of the De Interpretatione prologue, Ockham presents the mental-act theory of concepts and offers a limited defense of it. In the course of this discussion, he considers a number of objections that might be raised to the theory and then goes on to provide what he takes to be the best response available to one wishing to hold this view. Among the objections he considers is one that specifically challenges the mental-act theorist to explain what, in the absence of ficta, serves as the object for acts of judgment. Although the challenge is stated specifically in terms of objects of judgment, the problem it poses is perfectly general (and by now also familiar) - namely, how, on the mental-act theory of concepts, the problem of intentionality is to be resolved.

47 In the prologue of his commentary, Ockham begins by calling attention to Aristotle's claim that words primarily signify concepts ('passiones mentis') and then proceeds to note that there is considerable debate about 'what kind of thing a concept is.' While acknowledging that questions about the nature of concepts do not pertain directly to the broadly logical issues with which Aristotle is concerned in the De Interpretatione, Ockham takes the issue up anyway saying that '[while this] does not pertain to logic but to the considerations of metaphysics, nevertheless, I want to go over some opinions that can be held on this difficult matter.' Expos.Perih. Prol., sec. 3 (OPh II, 349). 
The objector puts the challenge as follows: 'Consider,' he says, 'the act of knowing a proposition. I ask what is understood by such an act?' The objector then proceeds to argue that the only way to account for the object of this act is to introduce some sort of mind-dependent entity to serve as object. For, as he explains, the object for such an act

(E) Is either [1] something simple or [2] something composite. But it is not [1] something simple, since every proposition is at the very least composed of a subject and a predicate and a copula. But if it is [2] something composite, I ask this: from what is this proposition composed? Either it is composed entirely out of [2a] things in extramental reality (res) - in which case the proposition would exist in extramental reality and not only in the intellect. Or it is composed from [2b] things in the intellect, [in which case it is either composed from [2bi] acts of understanding, or from [ $\left.2 \mathrm{~b}_{\mathrm{ii}}\right]$ other things in the intellect.] But it cannot be composed from $\left[2 b_{i}\right]$ acts of understanding, since [if it were composed entirely of such acts], then, in addition to the act of understanding the proposition, there would also be the other acts from which the proposition is composed. And, if this were the case, there would be many acts existing simultaneously. Therefore, $\left[2 b_{i i}\right]$ some other thing is understood by the act of understanding, which is nevertheless [composed from things] in the intellect. ${ }^{48}$

Essentially, the objector's strategy is to prove that the mental-act account of concepts must be abandoned in favor of a view positing some sort of mental object beyond the acts themselves. The argument may be summarized as follows:

(1) Thinking (e.g. understanding or knowing) consists in a relation between an act of thinking and what is thought of. (The relational analysis of intentionality)

(2) Hence, objects of propositional acts (such as knowing) are complex or propositional in nature.

(3) Such complex, propositional objects must be composed either from things in extramental reality or from things in the mind.

(4) They cannot be composed of things in extramental reality (since this would entail that there are propositions in the world).

(5) Hence, they must be composed from things in the mind.

(6) If they are composed from things in the mind, they must be composed either of mental acts or other mental items. 
(7) But they cannot be composed of mental acts (since this would entail the simultaneous existence of several mental acts namely, the act of judging or knowing a proposition, and the acts of apprehension that comprise the propositional object). ${ }^{49}$

(8) Hence, they must be composed of other mental items.

The objector doesn't specify in his conclusion what kind of mental items propositional contents must be composed of - whether ficta or something else. But the argument is clearly pushing in the direction of something like the fictum view.

Ockham's response to this objection begins by drawing attention to an ambiguity in the objector's question. The objector asks about 'what is understood by an act of knowing a proposition' and so appears to waiver between asking about the nature of the objects of (propositional) understanding (i.e., acts of propositional apprehension), on the one hand, and about the nature of the objects of knowledge (i.e., acts of judgment), on the other. To this, Ockham responds by pointing out that it is important whether we are speaking of the act of knowing a proposition or of an act of apprehending a proposition' - thereby intending to leave open that the question can be answered differently depending on which type of mental act we have in mind.

It is puzzling that Ockham should emphasize the distinction between apprehension and judgment at this point - we would expect that whatever account he gives of the objects of propositional attitudes, it's going to be the same regardless of whether the attitude in question is one of apprehending or one of judging. As it turns out, however, this is not the case. Indeed, Ockham insists that if the argument is interpreted as applying to apprehension, it goes wrong for one reason, but if it is interpreted as applying to judgment, it goes wrong for another. As will become clear, Ockham's response to the objection embodies a kind of disjunctive analysis of intentional states, one that pertains to apprehension, another to judgment. In the end, I will suggest that Ockham's acceptance of such a disjunctive analysis has to do with his failure to be consistently clear about two different kinds of intentionality (namely, content vs. referential intentionality) and that this, in turn, is what leads him to analyze different kinds of mental state differently.

49 There was considerable debate (both before Ockham and after him) about whether there can be more than one mental act in the intellect at a time. As we shall see, Ockham finds nothing worrisome about granting this possibility. 
To see this, we need to begin by looking at his response to the objection as it applies to apprehension.

\section{Intermediate Theory of Apprehension}

As applied to apprehension, we can think of the objection as challenging Ockham to provide some account of the objects of propositional apprehensions. If mind-dependant objects do not serve as the relata for such acts, then what does? Ockham's response runs as follows:

(F) To apprehend a proposition is nothing other than to form a proposition. And when it is asked what is understood (intelligitur) by such a mental proposition - whether it is something simple or something composite - one can say that [it is] neither something simple nor something composite. ${ }^{50}$

Ockham's remarks here are somewhat cryptic, but at least this much is clear: he wants to deny that acts of propositional apprehension have objects that are either simple or complex. What this means, of course, is that Ockham means to reject premise (2) of the objector's argument, namely, the claim that propositional apprehensions relate to complex, propositional objects. Thus, whereas in earlier discussions of apprehension (e.g., in passage (A)) Ockham explicitly characterizes propositional apprehension in terms of its relation to something complex (complexi), here he abandons this view.

Initially, Ockham's way of putting things seems puzzling, since to deny that a given mental act has a complex or propositional object suggests that the act in question is not propositional in content. Indeed, if we are assuming that a mental act's possessing content consists in its being related to a certain object, then to claim, as Ockham does here, that propositional apprehensions have neither simple nor complex objects would seem tantamount to claiming that propositional apprehensions are, as it were, empty. But clearly Ockham does not mean to commit himself to either claim - that is, either to the claim that propositional apprehensions are empty or to the claim that they are non-propositional in content (after all, he explicitly says that such apprehensions are apprehensions of propositions!) How, then, are we to make sense of Ockham's response to the objector's argument?

50 '...apprehendere propositionem non est aliud quam formare propositionem. Et tunc quando quaeritur quid intelligitur tali propositione in mente: aut simplex aut compositum? -potest dici quod nec simplex nec compositum' Expos.Perih. Prol., sec. 6 (OPh II, 357). 
The key lies in recognizing that Ockham's discussion in this passage, and, in particular, his rejection of premise (2) of the objector's argument is motivated by a more general alteration in his conception of intentionality. Indeed, Ockham's rejection of premise (2) can be explained by the fact that he now means to reject premise (1) as well, namely, to reject the relational analysis of intentionality - at least for cases of apprehension. This, I take it, is the point of his claiming that 'to apprehend a proposition is nothing other than to form a proposition.' Since the very locution 'apprehend a proposition' suggests a relation to a distinct, independent entity, Ockham means to draw attention away from it by recommending that we conceive of propositional apprehension as an act of 'forming' or 'thinking' a propositional thought. Indeed, as Ockham understands the mental-act account of apprehension, to apprehend a proposition is not to stand in some intentional relation to a given object (whether simple or complex); rather it is just to possess an act (or, as we might say, to occupy a state) of the relevant sort, one which is, as it were, propositionally contentful. Ockham expresses all this a bit more clearly later in the prologue when he explains what it means, on the mental-act account, to say that we apprehend or understand propositions:

(G) It should not be said that a mental proposition is understood [i.e., apprehended] in such a way that it is the terminus of an act of thinking.... If we take being understood (intelligi) as related to understanding (intellectionem) in a way similar to that in which being spoken (proferri) is related to an utterance (vocem), then [we can see that] just as to utter is to bring about a spoken word, similarly, to understand is to bring about or to possess an understanding. ${ }^{51}$

Thus, when Ockham claims (as he does earlier in passage $(F)$ ) that propositional apprehensions do not have complex, propositional objects, it is clear that what he means to deny is not that such apprehensions are propositional in content, but only that their having the content they do consists in a relation to some object - whether simple or complex.

Although Ockham rejects premise (1) as applied to apprehension, it is important to note that he does, nevertheless, allow that there is $a$ sense in which propositional apprehensions can be said to be directed at objects. In fact, in the text immediately following the passage quoted at $(F)$, Ockham hastens to add that, when we entertain a propositionally contentful thought such as 'a human being is an animal,' there are certain

51 '...non debet proprie loquendo concedi quod propositio in mente intelligitur ita quod terminet actum intelligendi...Sed accipiendo 'intelligi' ut similiter se habeat ad intellectionem sicut 'proferri' se habet ad vocem, ita quod sicut 'proferre' est causare vocem ita 'intelligere' sit causare vel habere intellectionem. Expos.Perih. Prol., sec. 12 (OPh II, 375). 
entities - namely, individual human beings and animals - to which the act relates. He is careful in this passage to indicate, however, that such objects in no way function as the content of the state:

(H) Properly speaking, by the proposition 'a human being is an animal' neither a simple [object] nor a composite [object] is apprehended. Rather that mental proposition is an act of understanding by means of which every human and every animal is confusedly apprehended and [by means of which it is apprehended] that a human is the same in number as an animal - since this is what is expressed (denotatur) by means of the proposition. Therefore, by this proposition many things are understood, yet not something that is composed [from them]. ${ }^{52}$

Here Ockham explains that although the apprehension (namely, the apprehension that a human being is an animal) relates to human beings and to animals as objects, what the act represents is 'that a human is the same in number as an animal' - and this (namely, the act's representational content), he maintains, 'is not something composed' from humans and animals. This distinction between what the propositional apprehension represents and what serves as its object shows fairly clearly that, at least in the case of propositional apprehension, Ockham is now committed to a distinction between a mental act's possessing representational content and its being related to or directed at certain objects.

To the extent that Ockham is committed to this distinction between an act's having content and its relating to an object, he is also clearly committed to what I earlier referred to as the distinction between content and referential intentionality. For a mental state has content intentionality just in case it has representational content, and it has referential intentionality just in case there is an object to whick it relates in virtue of having the content it does. ${ }^{53}$ To say that Ockham is committed to these distinctions, however, is not to say that he fully or consistently recognizes them. To see this, we need only turn to his intermediate account of judgment.

52 Expos.Perih. Prol., sec. 6 (OPh II, 357-8).

53 What the foregoing makes clear, therefore, is that Ockham's rejection of premise (1) is a rejection of a relational analysis of content intentionality, but this still allows for a relational analysis of referential intentionality. That is, Ockham can and does still allow that mental acts, in virtue of their content, may relate or refer to certain objects. Hereafter, I will ignore this complication. Thus, in what follows, when I speak of Ockham adhering to or rejecting a 'relational analysis of intentionality,' I mean only to be speaking about his analysis of content intentionality. 


\section{Intermediate Theory of Judgment}

Having seen how Ockham replies to the objector's argument as applied to apprehension, we might expect him to reply in a similar manner when he considers its application to judgment. That is to say, having rejected the relational analysis of content intentionality for the case of apprehension, we might expect him to do the same for judgment as well. In fact, however, this is not what Ockham does. Instead, when he turns to acts of judgment and their objects, he seems to blur the very distinction at the heart of his reply in the case of apprehension - that is, between content and referential intentionality. Thus, in the case of judgment, Ockham does not deny either (1) or (2) of the argument, but assumes along with his objector that acts of judgment must always be related to or terminate at propositions - where propositions are taken as objects that constitute the judgment's content. As he explains:

(I) If we speak of the act of knowing some proposition, then it can be said that this act is an act that is distinct from the act [of apprehension] that is the proposition. And, therefore, when some mental proposition is known, there are two acts of the intellect occurring simultaneously, namely, the act that is the proposition and the other act by means of which the proposition is known. Nor does one ever find Aristotle denying that two acts of the intellect can exist at the same time in the intellect, especially when it comes to acts ordered in the way these are: proposition and act of knowing it. ${ }^{54}$

As this passage makes clear, Ockham still construes the content of a judgment (in this case, an act of knowledge) as an entity, distinct from the act and to which it relates. Thus, when it comes to providing an analysis of judgment, at least during the intermediate stage of his development, Ockham simply sticks to his early relational analysis - including his early tendency to overlook the distinction between a state's content and referential intentionality. Initially, therefore, on the mentalact account, as on the fictum account, acts of judgment relate to propositions as their object.

This is not to say that the account of judgment undergoes no change at the intermediate stage. On the contrary, Ockham's analysis of propositions as propositionally contentful acts of apprehension requires him

54 'Sed si loquamur de actu sciendi aliquam propositionem, sic potest dici quod ille actus est alius actus a propositione. Et ideo quando aliqua propositio in mente scitur, tunc sunt duo actus intellectus simul, scilicet ipsa propositio et actus alius quo scitur illa propositio. Nec unquam invenitur ab Aristotele quod negaret duos actus intellectus posse simul esse in intellectu, maxime de actibus ordinatis cuiusmodi sunt propositio et actus sciendi eam' (Expos.Perih. Prol., sec. 6 OPh $\Pi, 358$ ). Cf. Section 12 (OPh II, 375) where Ockham says much the same thing. 
to concede that what serves as the object for judgments are other mental acts. Indeed, it is this concession that determines his response to the objector's argument as applied to judgments. Instead of rejecting the first and second premises, as he had done in the case of apprehension, he now responds by rejecting premise (7) - which is just to say he admits the possibility of several mental acts existing in one person simultaneously. Unlike his opponent, however, Ockham claims to find nothing incoherent or even particularly problematic about allowing for this possibility - at least when the acts in question are ordered as 'proposition and act of knowing it.'

What is characteristic of Ockham's intermediate theory of judgment, therefore, is that it is based on a kind of disjunctive analysis of intentional states. With regard to apprehension, Ockham denies the relational analysis. Acts of propositional apprehension, he claims, do not possess their propositional content in virtue of a relation to a propositional entity rather such acts just are propositions, that is, they are acts that are, in themselves, propositionally contentful. While acts of apprehension may relate to certain objects, the relation they bear to such objects does not constitute their possessing the content they do. With regard to judgment, however, he insists that the relational analysis of content intentionality still holds. Acts of judgment, he still maintains, relate to propositions as providing their content.

There is, of course, something puzzling about all of this. We would expect Ockham to provide a uniform analysis of intentional states, and in particular to have invoked the distinction between content and referential intentionality in the case of judgment, since he'd already done so in the case of apprehension. That he fails to do so, I believe, owes to the fact that when he first begins to entertain the mental-act theory of concepts, he simply does not fully appreciate all of its implications for his early relational analysis of intentionality. This is not to say, however, that this intermediate theory is merely a residue of Ockham early thinking about judgment during a period of transition. For, although Ockham holds this intermediate theory for a short time, it does appear to be a considered position - one that he not only has some reason to defend, but also one that he became notorious for holding. ${ }^{55}$

55 Indeed, although the only textual evidence for this position comes from the period during which Ockham vacillates between the fictum and mental-act theory of concepts, it seems he did take this 'intermediate' theory of judgment seriously. For, even as he began to prefer the mental-act theory of concepts he seems to have continued to defend his early view that acts of judgment terminate at mental propositions. In fact, the evidence suggests that Ockham abandoned this view only 
In fact, we can begin to understand how Ockham could have arrived at this disjunctive position if we note that in the case of propositional apprehension the mental-act account of concepts forces Ockham to a rejection of the relational analysis, whereas it provides no such impetus in the case of judgment. To see this, we need only observe that adopting the mental-act account of concepts raises the problem of intentionality all over again - at least in the case of apprehension. For what, in the absence of ficta, is to serve as the object for thoughts involving non-existents? Clearly, Ockham cannot appeal to mental entities such as ficta to provide the content for propositional apprehension, and he will not countenance propositional entities (e.g. propositions, facts, or states of affairs as they are nowadays conceived) in extramental reality. Thus, the only recourse for him is to reject the assumption that an apprehension's possessing content consists in a relation to some object - that is, to reject the relational analysis of content intentionality.

Accordingly, as we noted above, Ockham moves from thinking of acts of propositional apprehension as having mental propositions as objects to thinking of such acts as themselves being mental propositions. Notice, however, that the same pressure to abandon the relational analysis is not present in the case of judgment. For if acts of apprehension are themselves thought of as propositions, there is no problem finding objects for acts of judgment. Acts of apprehension themselves can play this role. And, given Ockham's early assumptions about the logical ordering among the intellect's various acts, it follows that judgments are always going to be preceded (logically) by a propositional apprehension. For every judgment there will be a prior propositional apprehension to serve as its object (that is, as its content). Thus, when Ockham first begins to develop the mental-act account of concepts, there may have seemed to be little need to alter his early view of judgment as directed at mental propositions.

What is more, there are further considerations that provide Ockham with considerable impetus not to abandon the relational analysis in the case of judgment. For example, Ockham's early characterization of judgment (namely, as mental assent (or dissent) to a proposition) naturally lends itself to a relational interpretation. In addition, as Ockham envisions it, the process leading up to the formation of a judgment is one in

under fire of criticism from Walter Chatton. Indeed Chatton, who criticizes Ockham's intermediate theory of judgment at length, appears to have played a significant role in convincing Ockham that this intermediate view is untenable. I examine the role Chatton plays in the shaping of Ockham's final theory of judgment elsewhere. See Brower-Toland, forthcoming. 
which a subject begins by merely entertaining (that is, apprehending) a given content and then goes on to adopt a certain attitude (namely, assent or dissent) with respect to that same content. The fact that the content of the judgment and the apprehension (logically) preceding it is the same leads Ockham to suppose that the proposition apprehended and judged must be numerically the same entity. And since, on the mental-act account of concepts, the proposition apprehended is identical to an act of apprehension he concludes that acts of judgment are acts directed at prior propositional apprehensions. ${ }^{56}$

In light of all this, we can now see that commentators have been right in thinking that even when Ockham begins to entertain the mental-act account of concepts he continues, at least for a time, to adhere to his earlier view that judgments are acts that relate to mental propositions as (content) objects. It is less clear, however, that such commentators are right in their assessment of the resulting theory. According to Pasnau, for example, whose views we've already had occasion to mention, if judicative attitudes such as knowledge and belief are directed at mental acts or states as items that provide their content, then judgment is nothing but a kind of self-knowledge. On this view, he says:

what one knows is a proposition and a proposition is equivalent to an act of apprehending. Hence, knowing that human beings are animals is equivalent to knowing one's apprehension that human beings are animals. But knowledge of the latter sort seems to be self-knowledge; it seems to be knowledge about what one is thinking. And it seems quite odd to hold that the knowledge that humans are animals is knowledge about one's thoughts. ${ }^{57}$

Because Pasnau believes that this theory represents Ockham's last word on the matter, he takes its counterintuitive nature to show that Ockham

56 In addition to these sorts of considerations, Ockham's views about the nature of demonstrative scientia must also be taken into account, for his views the nature of objects demonstrative knowledge help to explain his views about objects of judicative attitudes in general. For when it comes to the objects of demonstrative knowledge (which Ockham refers to as 'knowledge strictly so-called'), Ockham insists throughout his career that 'every science whatsoever - whether it is real or rational - concerns only propositions. For it concerns those things which are known and only propositions are known' (Ord.d.2, q.4 OTh II, 135). As we shall see in section 3.2 , Ockham finds a way to maintain this claim about objects of demonstrative science - even in his most mature account of judgment. No doubt his views about propositions as objects demonstrative knowledge help to explain his general unwillingness to give up the claim that acts of knowing or judging in general relate to mental propositions as object.

57 Pasnau 1997, 289 
ultimately fails to provide a satisfactory theory of judgment. Here, however, Pasnau not only fails to see that this is not Ockham's final word, but also fails to appreciate the details of Ockham's views about apprehension at this stage of development. For if, as Ockham supposes, acts of apprehension involve direct cognitive relations to things in the world, then it's fair to say that acts of judgment, in virtue of being related to acts of apprehension, also involve cognitive relations to the external world. Indeed, Ockham could respond by pointing out that acts of judgment have external as well as internal objects. That is to say, it is perfectly compatible with his intermediate view to say that while the act of judging that human beings are animals relates to an act of apprehension as providing its representational content, it nevertheless has human beings and animals themselves as its (referential) objects.

Still Pasnau might insist that Ockham's intermediate view is counterintuitive insofar as it entails that judgment must involve some kind of cognition or awareness of other mental states. For insofar as judgments, on this view, are attitudes directed at prior acts of apprehension, it would seem that they involve at least some cognition or awareness of those acts of apprehension. Elizabeth Karger raises just this point in her discussion of Ockham's views on judgment. She says:

\footnotetext{
It would then follow [from such an account of judgment] that all knowledge and belief would involve an introspective awareness of one's own mental acts. But this is surely an unacceptable consequence, since there are undoubtedly cases of knowledge and belief where the agent remains wholly unaware of the workings of his own mind. ${ }^{58}$
}

Thus, like Pasnau, Karger thinks there are problems associated with this theory. Unlike him, however, she takes them not as evidence that Ockham's final account is unsatisfactory, but rather as evidence that he never held such a theory in the first place. Appealing to Ockham's later discussion in his Quodlibetal Questions, she argues that when Ockham moves to the mental-act account of concepts, he abandons his early view that all judgments relate to propositions.

Regardless of the difficulties Pasnau and Karger find in foregoing account of judgment it is clear that they both draw the wrong conclusions from them. In particular, they fail to recognize that this theory of judgment is an intermediate theory: pace Karger it is a theory that Ockham was, for a time, willing to endorse, but pace Pasnau it is also a theory he later abandoned. Indeed, as it turns out, Ockham himself - rightly or not - 
comes to motivated by the very sorts of considerations raised above to abandon this intermediate view and to move to his third and final theory of judgment.

\section{Ockham's Third Theory of Judgment}

Ockham's most mature treatment of judgment occurs in his Quodlibetal Questions. He discusses judgment at several places in this work, but in what follows I focus primarily on his account in Quodlibet 3, question 8 (hereafter ' $Q .3 .8^{\prime}$ ), since this question contains his most complete treatment of the issue. ${ }^{59}$ Before turning specifically to this discussion, however, a few general remarks are in order.

As will become clear, one of the most distinctive features of Ockham's third and final theory of judgment is a distinction he introduces between two types of judicative act - direct and reflexive. This distinction is a special case of a distinction Ockham now draws between 'direct' and 'reflexive' mental acts generally. As Ockham explains it, 'an act by which we understand an object outside the mind is called a direct act, and an act by which a direct act itself is understood is called a reflexive act. ${ }^{, 60}$ What Ockham here refers to as a 'direct' mental act, we might perhaps think of as a first-order act, that is, as a state involving an awareness only of items in the extra-mental world. Reflexive acts are, by contrast, second-order acts; they are acts involving awareness of other, first-order mental acts. Although Ockham does not in any way restrict this distinction to acts of judgment, it is, nevertheless, a distinction to which he returns explicitly (and perhaps most frequently) when treating questions about judicative acts and their objects. ${ }^{61}$

59 Ockham discusses judgment in Quodl. III, q. 8; IV, q. 16; V, q. 6 (OTh IX). Ockham's Quodlibeta Septem is translated by Freddoso and Kelly (see Ockham 1991). I adopt, with some modification, their translation.

60 Quodl. II, q. 12 (OTh IX, 165). Ockham utilizes the distinction between direct and reflexive acts in many places throughout his Quodlibeta.

61 In these contexts, Ockham often does not mark the distinction, using the terms 'direct' and 'reflexive'; nonetheless, in every place he discusses judgment Ockham makes clear that there are direct and reflexive judgments. For example, in Quodl. IV, q. 16 he begins his discussion of judgment by pointing out that 'acts of assenting are of two sorts. One sort is an act by which I assent that something is or is not such-and-such in the way that I assent to its being the case that God exists, and to its being the case that God is three and one, and to its being the case that God is not the devil.... The second sort of assent is an act by which I assent to something, with the result that the act of assenting bears a relation to something, in the way that I assent to or dissent from a propositional sign' (OTh IX, 376-7). 
For ease of exposition, in what follows, I focus - at least initially just on Ockham's treatment of direct acts of judgment. As Ockham himself recognizes (see passage $(J)$ below), in the ordinary course of things, most judgments are direct or 'first-order' in nature. After all, when we form a belief (or other judicative attitude) we typically do so without any reflexive awareness of our own mental states. In this respect, first-order judicative attitudes represent the paradigm case of judgment. Even so, in order to complete our account of Ockham's third and final theory judgment we will eventually need to take into consideration what he says about second-order judicative acts. I will, therefore, return to Ockham's account of reflexive judgments presently.

\section{Objects of Judgments: The Final Account}

By the time Ockham comes to write the Quodlibetal Questions, he has finally and fully abandoned the fictum theory of concepts. Accordingly, in Q.3.8, Ockham is presupposing the mental-act theory and so is, once again, addressing issues associated with the problem of intentionality. In particular, he is responding specifically to a question about the nature of objects of judgment. The issue here is not unlike the one Ockham deals with in the De Interpretatione prologue; thus, the question to which Ockham is now responding is 'whether an act of assenting has as its object something complex or something non-complex?'

This time around Ockham responds by rejecting the claim central both to his intermediate account of judgment in the De Interpretione and to his early (fictum) theory of judgment. In particular, he now rejects the claim that judicative attitudes relate to or terminate at propositions. And we've already anticipated his reason for denying this claim: Ockham worries that its acceptance would require that every judgment involve some kind of self-knowledge, that is, some kind of second-order cognition of one's own mental states.

(J) Speaking of the first [i.e. direct] sort of assent, I claim that such an act does not have a proposition (complexum) as its object because such an act is able to exist through the mere formulation of a proposition and without any apprehension of a proposition. For this reason, it cannot be an act of assenting to a proposition. Furthermore, when an ordinary person knows that a rock is not a donkey, he is not thinking about a proposition at all and, as a result, he is not assenting to a proposition. $^{62}$ 
In this passage, Ockham denies that an act of judgment - or more specifically, an act of assent - has a proposition as its object on the grounds that this would entail some apprehension or awareness of the mental state that is the proposition. For as we've seen, on the mental-act theory of concepts, propositions are just a certain type of mental state, namely, a state of propositional apprehension. Thus, any act of judgment that has a proposition as its object would seem to require some awareness of another mental state. But, as Ockham points out, we form all kinds of judgments without any consciousness of our own thoughts or mental states. Thus, he concludes that such judgments do not have mental propositions as their object.

But then, if propositions are not the objects of acts of judging, what are we to say about their objects? Ockham's response at this stage will have a familiar ring. Strictly speaking, he says, there are no objects for these judicative attitudes: 'if you ask whether a thing is known by this act, I reply that, properly speaking, one should not say that a thing is known by this act.' Or, as he puts it at another point in the same discussion, 'literally speaking, nothing is believed by such an act [of believing], just as nothing is known by an act of knowing.' Here we find Ockham making the same kind claim about judgment that he made about propositional apprehension on the intermediate theory. And here again he overstates the point for the sake of emphasis. In denying that acts of judgment have objects, he does not mean to suggest that such acts are empty or lack propositional content. In fact, he leaves no room for doubt about this. For immediately after claiming, 'one should not say that a thing is known by this act,' he hastens to add that one should say 'rather that by this act it is known that a rock is not a donkey. ${ }^{63}$ Thus Ockham's point is not to deny that judicative acts have propositional content, but merely to distinguish their possessing such content from their relating to a proposition as their object.

The significance of all this should be clear: Ockham is, at last, bringing his account of judgment in line with his intermediate account of apprehension. He now wants to say that even in the case of judgment there is no object to which the act of judging as its representational content. Thus, believing, knowing, or otherwise assenting to (or dissenting from) a given propositional content is not to be analyzed as a relation between

63 Interestingly, some (e.g. Gaskin 2003, n.3) have taken Ockham's remarks in this context to imply that he means to introduce entities of a new ontological type facts or states of affairs - to serve as objects of judgment. It seems clear, however, that Ockham doesn't mean to be quietly changing his ontological commitments, but rather just specifying the content of the judicative state in question. 
an act of judgment on the one hand and a proposition on the other. Rather, to believe, or know (etc.) a proposition is just to possess an act (or, as we might say, to occupy a state) of assent that, is itself propositionally contentful. In other words, Ockham is now committed to a non-relational analysis of intentionality - both for apprehension and for judgment.

Here again, however, it is important to recognize that denying a relational analysis of content intentionality does not thereby entail that judicative attitudes bear no relation to extra-mental objects. Quite the contrary. Ockham insists that when we form these sorts of judgments, we are judging about - and, hence, stand in some sort of intentional relation to - things in extramental reality. Consider, for example, what he says about the previous example of judging that a rock is not a donkey:

(K) Although it is by means of a proposition formulated in the intellect that one affirms and knows that things are such and such in reality or that things are not such and such in reality, one nonetheless does not perceive this [proposition]. Instead, the act of assenting has as its object things outside the mind, namely, a rock and a donkey. And yet it is not the case that a rock is known or that a donkey is known; rather, what is known is that a rock is not a donkey. ${ }^{64}$

What Ockham tells us here is that although 'an act of assenting has as its object things outside the mind,' nevertheless, such objects are not what 'is known' by the act of assenting. Ockham's explicit distinction between the content of an act of assenting (e.g., that a rock is not a donkey) and what serves as its object (e.g., rocks and donkeys) shows that he now recognizes, in the case of judgment as well as apprehension, the distinction between content and referential intentionality. Accordingly, Ockham allows here, as in the case of apprehension, that although the judgment's having content does not consist in its being related to one or more objects, it can, nevertheless, be said to relate to extramental entities (rocks and donkeys) as objects - but only insofar as they are taken to be referential objects.

As all of this makes clear, Ockham's final theory of judgment now forms part of a unified account of intentionality. During the intermediate period, Ockham accepted a disjunctive account: he provided a non-relational analysis of intentionality for apprehension, but retained his earlier relational analysis in the case of judgment. In his third and final theory, however, Ockham makes a complete rejection of the relational analysis of intentionality, and thereby brings his account of judgment into conformity with his intermediate view of apprehension. 


\section{Mental Propositions as Objects of Knowledge?}

The Case of Reflexive Assent

In light of the foregoing, Ockham's account of reflexive judicative acts may seem somewhat surprising. For when Ockham considers what should be said about the nature of the objects for reflexive judgments, his response runs rather differently than it did in the case of direct acts:

(L) Speaking now concerning the second [namely, reflexive] act of knowing or assenting, I say that this [type of] act is, properly speaking, a propositional act that has a proposition as its object. For this act is one by which something true is known. But an external thing is not known, for I do not know a rock or donkey. ${ }^{65}$

On the surface, Ockham would appear to be returning (once again) to his earlier, relational analysis of judgment. Indeed, I suspect that Ockham's talk here, and throughout his later works, of knowledge having 'a proposition as its object' has tended to mislead commentators. For Ockham does, in all of his late writings (for example, in works such as his Summa Logicae and his Exposition of Aristotle's Physics - both of which are composed at roughly the same time as the Quodlibetal Questions), continue to speak of judicative attitudes - in particular, of knowledge (scientia) - as relating to mental propositions. ${ }^{66}$ Yet we need only keep in mind the distinction just mentioned between content and referential intentionality to see that there is no inconsistency here: such judgments have mental propositions as objects in precisely the sense that direct judgments have extramental entities (like rocks and donkeys) as objects. Indeed, in allowing that some judicative acts (namely, those that are reflexive) relate to mental propositions, Ockham is only acknowledging that there are at least some occasions on which we attend to and even form judgments about our own (first-order) mental states. For instance, we can judge about a given propositional apprehension (say, the firstorder apprehension that a rock is not a donkey) that it is true, say, or that it is false. And, in such cases, what the judgment in question refers to (and

65 Quodl. III, q. 8 (OTh IX, 234). Ockham repeats much the same point a bit later in the same discussion: 'Speaking concerning an act or habit of believing in the second [i.e. reflexive] way, [I say that] they have a proposition - for example, an article of faith - for their object. After all, nothing is believed unless it is true, and nothing is true except a proposition.'

66 See, for example, qq. 1-12 in Ockham's $S L$ III-2 (OPh I, 505-526) and passages from Ockham's Exposition of Aristotle's Physics such as that quoted in the introduction of this paper. In the passage I quoted earlier, Ockham claims that 'all knowledge (scientia) is in relation to a [mental] proposition or propositions.' 
so has as object) is not something in the extramental world, but is rather something in the mind - namely, a mental proposition.

Since Ockham makes quite explicit in his Quodlibetal Questions that it is only reflexive, or second-order judgments that can be said to have propositions for objects, we can also safely assume that when he claims, in other contexts, that knowledge relates to mental propositions, he is referring only to reflexive or second-order acts of knowing. ${ }^{67}$ Although in texts such as his Exposition of Aristotle's Physics or in the Summa Logicae treatment of Aristotelian demonstration Ockham doesn't explicitly mark the distinction between direct and reflexive acts, nevertheless, the overarching context makes perfectly clear that the kind of knowledge in question is, in fact, second-order. For in each of these texts, the knowledge about which Ockham is speaking is 'knowledge strictly so-called' (scientia propria dicta), a kind of specialized knowledge associated with the philosophical discipline of Aristotelian demonstrative science. ${ }^{68}$ Such knowledge is arrived at only via a demonstrative syllogism. But as Ockham explicitly points out in Q.3.8, demonstrative knowledge is reflexive in nature, since such knowledge amounts to an act of judging or assenting to the truth of a conclusion of a demonstrative syllogism:

(M) It is [the reflexive] act that philosophers are commonly speaking of. For they claim that the effect of a demonstration is a habit [or dispositional knowledge] that relates to a conclusion. Consequently, the [occurent] act corresponding to that habit is an act that relates to a conclusion as its object. Philosophers also claim that nothing is known except what is true, and they are speaking of a proposition. ${ }^{69}$

Here Ockham not only explicitly connects reflexive judgments with demonstrative scientia, but makes clear that such judgments are special

67 Claude Panaccio, in his discussion of reflexive judgment, makes a similar point about the relation between reflexive assent and acts of scientia. See Panaccio 2005, 35.

68 Aristotle's Posterior Analytics is, of course, the text in which he sets out the details of his theory of demonstration. Thus, for example, when Ockham discusses objects of knowledge, in SL III-2 (a treatment of the material from Aristotle's Posterior Analytics) it should be clear that the sort knowledge with which Ockham is concerned (and which he claims has mental propositions as objects) is demonstrative knowledge. Similarly, since according to Ockham, the Aristotelian science of physics is a demonstrative science, it is also the case that when speaking of objects of knowledge in the context of his commentary on Aristotle's Physics, Ockham must be understood as speaking about the objects of this demonstrative science.

69 Quodl. III, q.8 (OTh IX, 234). This passage follows immediately upon the passage quoted at (L) above. 
cases - cases in which what we are judging about, or giving assent to, is the truth of certain conclusions. In these cases, judgments do relate to mental propositions (conclusions understood as complex concepts), but here again the relation they bear to such propositions would appear to be a function of their referential intentionality.

Given this, we can now see that the mere fact that Ockham speaks of reflexive judgments and acts of scientia as relating to mental propositions provides no reason for thinking that he does not in fact ultimately reject the relational account of judgment or his early view that propositions constitute the content for judicative acts. Indeed, far from showing that Ockham vacillates in his rejection of earlier views, it reflects rather a level of clarity and sophistication present in his third and final theory. Once Ockham abandons the relational account of content intentionality for judicative as well as apprehensive attitudes, he's able not only to provide a unified account of mental content, but also to distinguish between firstand second-order mental acts and the type of object to which such acts (respectively) refer.

\section{Conclusion: Judgment, Intentionality, and Ockham's shift from Ficta to mental-acts}

I've now completed my argument for the claim that Ockham articulates not two, but three distinct theories of judgment. And, in light of this argument, we are now in a position to fully appreciate the way in which the developments in Ockham's account of judgment sheds light on broader developments in his philosophy of mind.

To begin, we have seen that the three-fold development in Ockham's thinking about judgment cannot be understood apart from a broader three-stage development in his thinking about intentionality. Ockham initially holds a relational analysis of intentional states; that is to say, he assumes that the representational content for a given intentional act is an object external to it and to which it relates. But as his views about the nature of concepts change, so too does his attitude toward the relational analysis. Thus, as we have seen, when Ockham first encounters the mental-act theory, he is willing to reject the relational analysis for a certain subset of mental states (namely, apprehensions), thereby giving rise to what I called his 'intermediate' or 'disjunctive' account of intentionality (since it presupposes one analysis for apprehensions, and another for judgments). It is only in the third and final stage of his thinking - the stage at which he unambiguously prefers the mental-act theory of concepts - that Ockham rejects the relational analysis for all intellective acts, apprehension as well as judgment. And part of the explanation for this final stage of development, we've now seen, is that at this stage Ockham 
finally comes to recognize fully and to apply consistently the distinction between content and referential intentionality.

Recognition of this evolution in Ockham's thinking about the nature of intentionality not only helps to make sense of the various changes in his account of judgment, but also seems to me to provide new insight into the way in which his views about concepts develop - insight that allows us to refine and extend the received account of his shift from the fictum to the mental-act account of concepts. Up to this point, I've left the developments in Ockham's views of concepts largely in the background in order to focus on his views about judgment and intentionality more generally. I want to conclude, however, by bringing this final feature of Ockham's philosophy of mind to the foreground.

By comparison with Ockham's views about judgment and intentionality, developments in his thinking about the nature of concepts have received a good deal of scholarly attention. ${ }^{70}$ Even so, scholars have tended to focus exclusively on the termini of this development - the fictum and mental-act theories, respectively — paying considerably less attention to the intermediate stage during which Ockham holds that the two theories are equally plausible. Unfortunately, this tendency to gloss over the middle phase has led scholars to overlook a problem with the received account of Ockham's motivation for abandoning the fictum theory of concepts.

As I've mentioned already, Ockham's rejection of the fictum theory is very often taken to be motivated entirely by metaphysical and epistemological considerations - in particular, by the considerations raised by his junior colleague, Walter Chatton. ${ }^{71}$ As we've seen, Chatton argues against the fictum theory on the grounds that ficta are (a) ontologically

70 Two recent, and extremely valuable, discussions of Ockham's developing views on concepts are Boler 2003 and Panaccio 2005, 21-36. The latter of these two discussions came into print only after I'd completed this paper. While Panaccio and I draw very different conclusions about the ultimate motivation for the development in Ockham's thinking about concepts, I was pleased to discover a surprising amount of common ground in the two discussions. For despite a variety of interpretive differences we seem, nonetheless, to share the view that the shift in Ockham's thinking about concepts is to be explained, ultimately, as a function of his coming to abandon certain early assumptions he held about the relation between mental acts and their objects. See Panaccio 2005, 23-27.

71 See, for example, Adams' (1977) account of the development in Ockham's account of concepts. Adams places special emphasis on ontological considerations as motivating the shift, going so far as to recommend that Ockham's 'change of mind be viewed as a reasoned ontological conversion' (145-6). See also Pasnau 1997, 76-86, 277-90. 
superfluous, and (b) epistemologically worrisome. While, I think there can be no doubt that these objections figure importantly in Ockham's thinking, I also think it's clear that they cannot, by themselves, explain the way his views actually develop. For if we assume that the ontological and epistemological considerations just mentioned are what ultimately motivate Ockham to abandon ficta, we are at once faced with the problem of explaining why these same considerations don't immediately motivate him to do so. We would expect that, once Ockham comes to be aware of Chatton's mental-act account, and so aware both of the metaphysical and epistemological problems for the fictum theory as well as of the possibility for developing a theory that makes no appeal to them, he would immediately adopt that alternate theory. The fact that he does not do so - but rather explicitly denies, during the intermediate stage, that the mental-act theory possesses any theoretical advantage over the fictum theory strongly suggests that there are additional considerations to be factored into Ockham's ultimate shift to the mental-act theory of concepts. Thus, in short, the problem with the received account of Ockham's developing views of concepts is that it cannot explain the intermediate stage in this development. ${ }^{72}$

If, however, we consider the intermediate stage in Ockham's thinking about concepts in light of the broader developments in his views about judgment and intentionality, his initial ambivalence toward the mentalact theory becomes perfectly intelligible. As we've seen, the intermediate stage of concepts corresponds to the intermediate stage of his thinking about judgment and intentionality. But during this stage, there is a perfectly good explanation for why Ockham's would regard the fictum and mental-act theories as theoretically on a par.

To begin, note that it is not at all clear, at this stage, that Chatton's epistemological objection to the fictum theory carries any weight. It is true that, on the fictum theory, intentional acts terminate (in at least some cases) at 'concepts' and, hence, that cognition turns out to be mediated by mind-dependent entities. But, at least as Ockham initially understands it, the mental-act theory carries the same consequence. For even on the mental-act theory, one must appeal to mind-dependent entities to serve as objects for certain intentional states (namely, judgments). But, then, in this respect the mental-act theory is really no better off than the fictum theory: both involve a commitment to mental intermediaries of

72 Boler (2003) raises and addresses a similar issue. Indeed, it is Boler who first suggested to me that my interpretation of the developments in Ockham's thinking about judgment and intentionality might provide some insight into the intermediate stage in his thinking about concepts. 
some sort; the only difference is in the nature of the intermediaries (mental acts in one case, ficta in the other) and in the acts which require them (judgments in one case, both judgments and apprehension in the other).

Much the same can be said for Chatton's ontological-parsimony objection. It is true that, insofar as the fictum theory invokes both mental acts and ficta, it appeals to more entities (or more types of entity) than the mental-act theory, which appeals to only mental acts. Even so, it is not clear that this, by itself, would have led Ockham to regard the mental-act theory as possessing a significant theoretical advantage over the fictum theory. For even on the mental-act theory, as Ockham construes it during the intermediate period, there is still an act-object distinction (at least for judgments), and thus we are still forced to admit two different ontological roles (namely, a mental-act role and an object role) in order to provide a complete account of intentionality. But here again we have a respect in which the mental-act theory offers no significant advantage over the fictum theory: insofar as both theories appeal to the same number of ontological roles in their analysis of intentionality, the mental-act theory cannot be regarded as theoretically simpler (or more elegant) than the fictum theory. Indeed, to the extent that the fictum theory appeals to a unified (as opposed to a disjunctive) analysis of intentionality, it appears to be the theoretically simpler (or more elegant) of the two.

What all of this goes to show, I think, is that we can explain Ockham's initial ambivalence toward the mental-act theory (and thus the intermediate stage in thinking about concepts) if (and perhaps only if) we place it in the context of his broader views about intentionality. Moreover, once we do this we can also appreciate why it is that Chatton's two criticisms eventually did come to seem so compelling. For it is only when Ockham finally gets clear about the distinction between content and referential intentionality, and thus fully grasps the possibility of a unified non-relational analysis of intentionality, that he is able to see that there is a form of mental-act theory that has just the advantages that Chatton claims for it. As Ockham explains, in the final stage of his thinking:

(N) In favor of [the mental-act theory] there is the principle that what is done through many is done in vain if it can be done with fewer. But everything preserved by positing something distinct from an act of thinking can be preserved without positing any such distinct thing.... Therefore, it is not necessary to posit anything beyond an act of thinking. ${ }^{73}$ 
Here it would seem that Ockham envisages a form of mental-act theory that rejects altogether the use of an act-object distinction to account for intentional content. In doing so, moreover, he recognizes that this form of mental-act theory, unlike the intermediate version, really does have a theoretical advantage: not only does it do with fewer types of entity (i.e., mental acts alone) what the fictum theory does with more (namely, mental acts and ficta), but it also avoids the excess of postulating distinct entities to play the ontological role of content. And, of course, in doing away with the need for postulating such entities, he also avoids postulating anything that would mediate between acts of thinking and their (referential) objects.

What emerges from all this, I believe, is that, as in the case of judgment, the development in Ockham's views about concepts cannot be understood apart from the developments in his broader views about intentionality. But this in turn just goes to reinforce the value of approaching Ockham's views on both concepts and intentionality from the perspective of his theory of judgment. For, if the argument of this paper is correct, Ockham's account of the nature of concepts and of the nature and structure of intentionality itself are closely bound up with - are indeed at times only observable from the vantage point of - his treatment of judgment. $^{74}$

Received January 2006

Revised August 2006

74 This paper has been improved at many stages in its development by valuable comments and criticism I've received from a number of people. In particular, I would like to thank John Boler, Alicia Finch, Carl Ginet, Bob Pasnau, Scott MacDonald, Scott Spiker, Jason Stanley, Zoltán Szabó, and especially Jeff Brower. I read a version of this paper at the 2004 Cornell Summer Colloquium in Medieval Philosophy and would like to thank the colloquium participants for useful feedback on that occasion. 


\section{References}

Adams, M.M. 1977. 'Ockham's Nominalism and Unreal Entities.' The Philosophical Review 86 144-76.

1987. William Ockham. Notre Dame, IN: Notre Dame University Press.

Addis, L. 1989. Natural Signs. Philadelphia: Temple University Press.

Aquila, R. 1977. Intentionality: A Study of Mental Acts. University Park: Pennsylvania State University Press.

Boehner, P. 1946. 'The Realistic Conceptualism of William Ockham.' Traditio 4 307-35.

1951. 'The Relative Date of Ockham's Commentary on the Sentences.' Franciscan Studies 11 305-16.

Boler, J. 1976. 'Ockham on Evident Cognition.' Franciscan Studies 36 85-98.

1982. 'Intuitive and Abstractive Cognition.' In The Cambridge History of Later Medieval Philosophy, N. Kretzmann, A. Kenny and J. Pinbourg, eds. Cambridge: Cambridge University Press.

.2003. 'Ockham on the Concept.' Medieval Philosophy and Theology 11.1 65-86.

Brower-Toland, S. 2002. Later Medieval Theories of Propositions: Ockham and the $14^{\text {th }}$ Century Debate at Oxford over Objects of Judgment. Diss., Cornell University.

Forthcoming. 'William Ockham and Walter Chatton on the Structure and Objects of Judgment.' In Intentionality, Cognition, and Mental Representation in Medieval Philosophy, G. Klima, ed. New York: Fordham University Press.

Caston, V. 1993. Towards a History of the Problem of Intentionality Among the Greeks. In Proceedings of the Boston Area Colloquium in Ancient Philosophy, J. Cleary and W. Wains, eds. New York: University Press of America.

1998. 'Aristotle and the Problem of Intentionality. Philosophy and Phenomenological Research 58 249-98.

Chatton, W. 2002. Reportatio super Sententias. J. Wey and G. Etzkorn, eds. Toronto: Pontifical Institute of Mediaeval Studies.

Crane, T. 2001. Elements of Mind. Oxford: Oxford University Press.

Findlay, J. 1963. Meinong's Theory of Objects and Values. Oxford: Clarendon Press.

Gál, G. 1967. 'Gualterri de Chatton et Guillelmi de Ockham controversia de natura conceptus universalis.' Franciscan Studies 27 191-212.

Gaskin, R. 2003. 'Complexe Significabilia and Aristotle's Categories.' In La tradition médiévale des categories (XIIe-XVe siècles), J. Biard and I. Rosier-Catach, eds. Louvain: Éditions Peeters.

Grassi, O. 1990. 'The Object of Scientific Knowledge in Some Authors of the Fourteenth Century.' In Knowledge and the Sciences in Medieval Philosophy. Proceedings of the Eighth International Congress of Medieval Philosophy, S. Knuuttila, R. Tyorinoja, and S. Ebbesen, eds. Helsinki: Luther-Agricola Society.

Haldane, J. 1989. 'Brentano's Problem.' Grazer Phlosophische Studien 35 351-62.

Harney, M. 1984. Intentionality, Sense, and the Mind. The Hague: Martinus Nijhoff Publishers. 
Haugland, J. 1990. 'The Intentionality All-Stars.' Philosophical Perspectives 4 383-427.

Karger, E. 1995. 'William of Ockham, Walter Chatton, and Adam Wodeham on the Objects of Knowledge and Belief.' Vivarium 33 171-86.

Kelly, F. 1978. 'Some Observations on the "Fictum" Theory in Ockham and its Relation to Hervaeus Natalis.' Franciscan Studies 38 260-82.

. 1981. 'Walter Chatton Vs. Aureoli and Ockham Regarding the Universal Concept.' Franciscan Studies $41222-49$

Kim, J. 1996. Philosophy of Mind. Boulder, CO: Westview Press.

Kretzmann, N. 1970. 'Medieval Logicians on the Meaning of the Propositio.' The Journal of Philosophy 67 767-87.

Leff, G. 1975. William of Ockham: The Metamorphosis of Scholastic Discourse. Manchester: Manchester University Press.

McDowell, J. 1998. 'Intentionality as a Relation.' Journal of Philosophy 95 471-91.

Normore, C. 1999. 'Some Aspects of Ockham's Logic.' In The Cambridge Companion to Ockham, P. Spade, ed. Cambridge: Cambridge University Press.

. 1987. 'Meaning and Objective Being: Descartes and His Sources.' In Essays on Descartes' Meditations, A. Rorty, ed. Los Angeles: University of California Press.

Nuchelmans, G. 1973. Theories of the Proposition: Ancient and Medieval Conceptions of the Bearers of Truth and Falsity. Amsterdam: North Holland Publishing.

1980. Late-Scholastic and Humanist Theories of the Proposition. Amsterdam: North Holland Publishing.

Ockham, W. 1967-89. Opera Philosophica et Theologica. St. Bonaventure, New York: St. Bonaventure University Press.

. 1990. Philosophical Writings. Ed. and trans. P. Boehner. Indianapolis: Hackett.

1991. Quodlibetal Questions. Trans. A. Freddoso and F. Kelly. New Haven: Yale University Press.

1994. 'Five Questions on Universals from his Ordinatio d. 2, qq. 4-8.' In Five Texts on the Medieval Problem of Universals, P. Spade, trans. and ed. Indianapolis: Hackett.

Panaccio, C. 1999. 'Semantics and Metaphysics.' In The Cambridge Companion to Ockham, P. Spade, ed. Cambridge: Cambridge University Press.

2005. Ockham on Concepts. Hampshire: Ashgate.

Pasnau, R. 1997. Theories of Cognition in the Later Middle Ages. Cambridge: Cambridge University Press.

Read, S. 1977. 'The Objective being of Ockham's Ficta.' Philosophical Quarterly 27 14-31.

Searle, J. 1983. Intentionality. An Essay in the Philosophy of Mind. Cambridge: Cambridge University Press.

Sellars, W. 1963. 'Being and Being Known.' In Science, Perception and Reality. London: Routledge \& Kegan Paul.

Spade, P. 1999. 'Ockham's Nominalist Metaphysics: Some Main Themes.' In The Cambridge Companion to Ockham, P. Spade, ed. Cambridge: Cambridge University Press. 
Tachau, K. 1988. Vision and Certitude in the Age of Ockham: Optics, Epistemology and the Foundations of Semantics 1250-1345. Leiden: E.J. Brill.

Wolenski, J. 1998/99. 'Twardowski on the Distinction between Content and Object.' Brentano Studien 8 15-35.

Woodruff-Smith, D. and R. McIntyre. 1982. Husserl and Intentionality: A Study of Mind, Meaning and Language. Dordrecht: Reidel. 